\title{
THE ANALYSIS OF RELIGIOSITY AND COUNTRY OF ORIGIN INFLUENCE TOWARDS PURCHASE INTENTION WITH CONSUMER ATTITUDES AS THE INTERVENING VARIABLE IN KFC PANDANARAN SEMARANG (CASE STUDY IN FE UNISSULA'S STUDENTS)
}

\author{
Edwin Hermanto*
}

\begin{tabular}{l}
\hline * Affiliation: \\
Universitas Islam Sultan \\
Agung Semarang \\
Email: \\
edwin19hermanto@gmail. \\
com
\end{tabular}
com

\begin{abstract}
:
This research aims to analyze the influence of religiosity and the county of origin against the purchase intention in KFC Pandanaran Semarang with consumer attitudes as intervening variable. The population in this research is a college student of economic faculty of Islamic University of Sultan Agung. The technique of the sample with a purposive sampling method and incidental sampling.Samples taken as many as 100 collage students, with a research instrument in the form of a questionnaire.Data analysis using SPSS 23.0. The results showed that religiosity and country of origin has a positive and significant effect on consumer attitudes. Country of origin and consumer attitudes has a positive and significant effect on the purchase intention. Religiosity has a negative and significant effect on purchase intention. Consumer attitudes not as intervening variables between religiosity towards purchase intention and between the country of origin towards purchase intention.
\end{abstract}

Keywords: Religiosity, Country of origin, Consumer attitudes, and Purchase intention.

\section{INTRODUCTION}

Come from within the country only. Many competitors coming from outside the country which plunged enliven business competition in the country. One of the businesses that were very promising at the moment is the culinary business. Based on the results of the population census conducted by the BPS, the total population of Indonesia in 2010 is as much $237,641,326$, with $87.18 \%$ of Indonesia's population is Muslim (www.bps.go.id). It makes Indonesia a very promising target market for any culinary business trade. One of the companies from abroad who come to enliven competition culinary business in Indonesia is KFC. KFC is a trademark of the franchise from Yum! Brands, Inc., 
headquartered in Louisville, Kentucky, United States (www.wikipedia.com. Based on the report data penjualanKFC in Indonesia from the year 2012 sampai2016 showed that KFC has always experienced an increase in sales from year to year. So this indicates that KFC was quite successful in its market share in Indonesia in Bandung. It is inversely proportional if we see which occur in countries that the majority of the inhabitants are Muslim, that the people there do a boycott against products which originated in the United States. Thus making the performance of sales of products of American decline. This is because the sense of form upset Muslims against the American policy which is always detrimental to countries that the majority of the inhabitants are Muslim. Based on cases that occurred on the loss of interest in buying in the form of a boycott of products made by the citizens of a country that is majority Muslim population against American products is influenced by a variety of variables, namely religiosity, country of origin, and consumer attitudes.

\section{LITERATURE REVIEW Purchase intention}

According to Kotler (2007), purchase intention is a decision to buy a brand among a variety of other brands. As for the purchase intention, it appears through a variety of processes, including the introduction of needs, information retrieval, evaluation information, and will eventually emerge a buy interest is inside a consumer. According to Mowen in Oliver (2007) purchase intention is the result of a process of learning and thought process against a wide range of information relating to a product, which then forms a perception of the form of boycott products performed by citizens of a country that is majority Muslim population against American products is influenced by a variety of variables, namely religiosity, country of origin, and consumer attitudes.

\section{Consumer attitudes}

According to Robbins (2006) is the attitude statements evaluative or assessment with regard to objects, people or an event. The attitude is seen as an effective predictor to know consumer behavior. According to Solomon (2009), consumer attitudes are judgments that do someone thoroughly to a product that is seen and perceived, which aims to get a conclusion to a product.

\section{Religiosity}

According to Glock and Stark in Ancok (2008), religiosity is an organized system that centered on issues that we appreciate it as the most meaningful, which consists of a system of symbols, a system of beliefs, value systems, and the system behavior. Religiosity leads to the quality of someone's life and attitude based on religious values that (Priest Ghozali, 2002:2). According to Johnson et al., (2001) religiosity is defined as how much a person committed to acknowledging religion adhered and his teachings, such as attitudes and behaviors that reflect this commitment. 


\section{Country of origin}

According to Ahmed, Johnson and Boon (2004) Country of origin is the country where the production or the Assembly that are identified as the label of "made in" or "in production". According to Listiana (2013), the country of origin or Country of origin information is often used by the consumer at the time of evaluating a product. Country of origin is an image of a product manufactured by a country.

\section{The influence of Religiosity towards Consumer attitudes}

People who have religiosity will behave in accordance with what has been taught by their religion. This is in accordance with the opinion of the Fetzer in research Priaji (2011:60), that religiosity is something that operates on the issue of social behavior, and is a doctrine of any religion or group. Therefore every follower of a religion is obliged to follow the doctrines of his religion. The higher the level of religiosity which belonged to someone, the more the people obey every command in the running of his religion. Not only the time of worship, people who have a high religiosity also affect her lifestyle every day, such as at the time of the interaction with other people, to speak a Word, works or at the time of purchasing a product. The attitude of the people in daily life will be according to what is being taught by their religion.

The results of the research conducted by Rohmatun and the Goddess (2017) stated that significant positive effect against religiosity attitudes. In line with that, the results of research conducted by the Zahri and Hafasnuddin (2017) also stated that the religiosity of positive affect significantly to consumer attitude.

$\mathrm{H}_{1:}$ Religiosity positively and significantly influenced the consumer attitudes.

\section{The Influence of Country of origin towards Consumerattitudes}

Country of origin can affect a person's attitude is he's going to have a positive attitude towards a country or being negative towards the country of origin of a product. Someone who has a positive attitude towards a country of origin of a product would be very willing to accept and use the products or services of those countries. In contrast, people who have a negative attitude towards a country will reject products and services from those countries. The rejection is due to the presence of taste does not like and shape one's protest against the existence of a country that has been extensively considered harming others.

The results of research conducted by Ramadania, Gunawan, and Jamaliah (2013) stated that there is a positive influence of country of origin against the attitude of the.

$\mathrm{H}_{2}$ : Country of origin positively and significantly influenced the consumer attitudes.

\section{The Influence of Religiosity towards Purchase intention}

Religiosity is a person's guidelines in the conduct of daily life is good for the interests of the world and in the hereafter. People who have high religiosity implements his religious knowledge of all aspects of his life. No exception on the economic aspects. Religion affects many aspects of life of the consumer. The Muslim people will buy a product that is allowed 
and in accordance with the teachings of Islam. For Muslims in the consumption activity, God Almighty commanded that take a lawful and toyyib.

The results of the research conducted by the Zahri and Hafasnuddin (2017) and Rohmatun and the Goddess (2017) shows that there is significant positive influence between religiosity towards purchase intention. Whereas, in research conducted by Abdolvand and Azima (2015) and Haque et al., (2015) stating that the religiosity of the negative and significant effect against the purchase intention. From the results of the research, there is research that shows the relationship between gap influence on religiosity towards purchase intention. So with regard to the difference between the results of such research, the author will do research to know how the anniversary of religiosity towards purchase intention.

$\mathrm{H}_{3}$ : Religiosity positively and significantly influenced the purchase intention.

\section{The Influence of Country of origin towards Purchase intention}

In the purchase of a product, consumers not only pay attention to the intrinsic factors but will also pay attention to extrinsic factors. Extrinsic factor besides the one brand is the country of origin. Country of origin itself better known by the public as the "made in" label. At the time of purchase of a product, consumers will see that product comes from which country. Consumers will be more interested in buying products from developed countries, in terms of quality and quality is no doubt.

The results of research conducted by Abdolvand and Azima (2015) States that the country of origin of the positive and significant effect against the purchase intention. In line with such research, research conducted by Dinata, Kumadji, and Hidayat (2015) also proves that the country of origin of the positive and significant effect against the purchase intention. The description can be drawn based on the hypothesis as follows:

$\mathrm{H}_{4}$ : Country of origin positively and significantly influenced the purchase intention

\section{The Influence of Consumer attitudes towards Purchase intention}

Attitudes towards a product could be caused by the presence of experiences personally experienced by a buyer, as well as the experience of others who then spread the good word of mouth or through the medium of the internet so affect the attitude that people in buying a product. Consumers who have a positive attitude towards a product would have the interest to buy against such products and vice versa that consumers have a bad experience against a product usually will no longer have interest in buying interest against the product is.

Research conducted by Ramadania, Gunawan, and Jamaliah (2013) shows that the attitude of influential positive interest toward the purchase. In line with this, some research stating that consumer attitudes positive significant effect against the purchase intention (Binalay, Mandey, and Mintardjo, 2016; Zahri and Hafasnuddin, 2017; Rohmatun and Dewi, 2017).

$\mathrm{H}_{5}$ : Consumer attitudes positively and significantly influenced the purchase intention. 


\section{RESEARCH METHODS}

The population in the study are all active students the morning classes Faculty of Economics University of Sultan Agung Islamic year 2014-2016 of 2,120 students. The sample used in this study as many as 100 students, with the technique of determination of the sample used is the purposive sampling and incidental sampling. The data collection methods used in this study using 2 way, i.e. with fieldwork to obtain primary data and research libraries to acquire secondary data. To measure the influence of religiosity and the country of origin against purchase intention with consumer attitudes as an intervening variable using the software SPSS 23.0.

\section{RESULT AND DISCUSSION The Influence of Religiosity towards Consumer Attitudes}

Religiosity influence on consumer attitudes, when levels of religiosity owned consumer good, then consumer attitudes toward products in KFC Pandanaran Semarang. Based on the responses of the respondents regarding religiosity variables shows that the respondents have a good enough level of religiosity. This indicates that consumers have a pretty good level of religiosity, that believes wholeheartedly the presence of Almighty God and the book of Allah SWT, the consumer is diligently implementing the Maghrib and read the Koran, consumers feel close to God Almighty, consumers know what is prohibited and that must be carried out in the Islamic teachings, consumers trying to always refuse to do things that are not good, then the consumer attitudes that consists of an indicator that is suitable and satisfied consumers buy products from KFC, consumers prefer KFC because of product in accordance with the tastes of consumers, consumers buying products of KFC because $\mathrm{KFC}$ is famous for its excellence taste their chickens, will also increase.

Thus the results of this study are in line with the results of previous research conducted by Rohmatun and Dewi (2017) and the Zahri and Hafasnuddin (2017) stating that religiosity influence on consumer attitudes.

\section{The Influence of Country of Origin towards Consumer Attitudes}

Country of origin effect on consumer attitudes, in the perception of the consumerowned against the country of origin of the KFC, is getting better, then consumer attitudes toward products in KFC Pandanaran Semarang will progressively increase. Based on the responses of the respondents regarding the variable country of origin shows that respondents have the perception and belief that good enough against the country of origin of the KFC. This indicated the perception of the country of origin of the KFC is good enough, that consumers chose American products because it is famous for its product innovation is good, has a high technology, the number of the diversity of the types of products offered, provided the quality of the products offered, the prestige attached to the United State, consumers chose American products because the country is a very advanced country, then consumer attitudes that consist of an indicator that is suitable and consumer satisfied purchase the products of KFC, consumers prefer KFC because of product in accordance with the tastes of consumers, consumers buying products of KFC because KFC is famous for its excellent taste their chickens, will also increase. 
The results of this research in line with the results of the preceding research committed by Ramadania, Gunawan, and Jamaliah (2013) stating that there is the influence of country of origin against consumer attitudes.

\section{The Influence of Religiosity towards Purchase Intention}

Religiosity influence on purchase intention, if religiosity owned the better, then the consumer purchase intention against the consumer products of KFC at Pandanaran Semarang will progressively increase. Based on the responses of the respondents regarding the variables of religiosity respondents shows have a reasonably good level of religiosity. This indicates that consumers have a pretty good level of religiosity that is consumers are convinced of the existence of Almighty God and the existence of the book of God Almighty, the consumer is diligent in performing the Maghrib and read the Koran, consumers feel close to God Almighty , consumers know what is prohibited and that must be carried out in the Islamic teachings, consumers trying to always refuse to do things that are not good, then the purchase intention which consists of indicators namely consumers eager to buy KFC product, consumers would recommend KFC to a friend nearby, consumers will choose the KFC fast-food restaurant than others, consumers already are looking for information on KFC products before buying, consumers will increasingly decline

The results of this research in line with the results of the preceding research committed by Abdolvand and Azima (2015) and Haque et al., (2015) stating that religiosity influence on purchase intention.

\section{The Influence of Country of Origin towards Purchase Intention}

Country of origin effect on purchase intention, if the perception against the country of origin of the KFC is getting better, then purchase intention against the product in KFC Pandanaran Semarang. Based on the responses of the respondents regarding the variable country of origin shows that respondents have the perception that good enough against the country of origin of the KFC. This indicates that consumers have the perception of the country of origin, i.e. the consumers who choose American products because of the famous product innovation is good, has a sophisticated technology, the number of variant types of products offered, the good quality of the product, the product could have the pride of America, consumers chose American products because the country is a very advanced country, then purchase intention that has indicators i.e. consumers wishing to purchase a product consumers would recommend $\mathrm{KFC}, \mathrm{KFC}$ to his friend, the consumer will choose the KFC fast-food restaurant than others, consumers already are looking for information on KFC products before consumers buy, will also increase.

Thus the results of this study are in line with the results of research performed by Abdolvand and Azima (2015) and Dinata, Kumadji, and Hidayat (2015) are researching and getting results that the country of origin effect on purchase intention.

\section{The Influence of Consumer Attitudes towards Purchase Intention}

Consumer attitudes influence on purchase intention, when the better consumer attitudes against KFC, then purchase intention against KFC at Pandanaran Semarangsemakin increases. 
Based on the responses of the respondents regarding the variables of consumer attitudes showed that respondent has quite good consumer attitudes towards products of KFC. This indicates that consumers have a pretty good consumer attitudes, i.e. consumers who already feel suited and satisfied buying products in KFC, consumers who like products KFC because according to the tastes of consumers, consumers buy products KFC because KFC is famous for its excellent taste their chickens, then the purchase intention which consists of indicators, namely the consumer wishes to purchase a product consumers would recommend KFC, KFC to his friends, consumers will choose KFC than restaurant other fast-food, consumers are already looking for information on KFC products before consumers buy, will also increase.

Thus research is in line with the results of the preceding research committed by Ramadania, Gunawan, and Jamaliah (2013), Binalay, Mandey, and Mintardjo (2016), Zahri and Hafasnudin (2017) and Rohmatun and the Goddess (2017) which States that consumer attitudes influence on purchase intention.

\section{The Influence of Religiosity towards Purchase Intentionthrough Consumer Attitudes}

Religiosity towards purchase intention through consumer attitudes contributions smaller than the contribution of religiosity is directly towards the purchase intention. Greater religiosity contributions directly affect purchase intention because consumers who have a fairly high level of religiosity making consumers lower their purchase intention against KFC products at Pandanaran Semarang. This is due to the large number of consumers who still have any doubt against halal KFC products, besides the existence of the issue in the public that KFC provides funds to Israel to fight the Palestinians, making consumers who have a level religiosity is a good choose directly lower the purchase intention against KFC products at Pandanaran Semarang.

\section{The Influence country of origin towards purchase intention through consumer attitudes}

The perception of the country of origin towards purchase intention through consumer attitudes contributions smaller than the contribution of the country of origin directly towards the purchase intention. The contribution of the country of origin of the larger directly affect purchase intention because consumers have the perception that good enough against the country of origin of KFC, making consumers have direct purchase intention against KFC products at Pandanaran Semarang, this is because consumers already feel confident with a product that is made from the United States that the country is a very advanced country. In making a product, the United State would've set a high standard of quality.

\section{CONCLUSION}

Religiosity is affecting consumer attitudes toward the purchase of products in KFC Pandanaran Semarang, this indicates that when consumers are confident and believe in the presence of Almighty God and the existence of the books of Allah, the consumer is diligently implementing the five salat time and an avid reader of the Koran, consumers feel close to God Almighty, consumers know what is prohibited and that must be carried out in the Islamic 
teachings, and consumers strive to always refuse to do things that are not good, will cause consumer attitudes towards products of KFC Pandanaran Semarang will also increase. Country of origin affects consumer attitudes toward the purchase of products in KFC Pandanaran Semarang, this indicates that when consumers have the perception that the country of origin of the KFC i.e. United States have a very good product innovation, sophisticated technology, the number of the diversity of the types of products offered, the quality of the product is very good, have prestige in can buy and have products from America, and the perception that the United States is a country a very advanced, will cause consumer attitudes towards products of KFC Pandanaran Semarang will also increase.

Religiosity influences the purchase intention on KFC products Pandanaran Semarang, this indicates that when consumers believe wholeheartedly the presence of Almighty God and the existence of the book of God, the consumer is diligently implementing the Ashar, consumers feel his prayers are often granted by Almighty God, consumers know what is prohibited and that must be carried out in the Islamic teachings, consumers trying to always refuse to do things which violate the teachings of Islam, will cause the purchase intention of product in KFC Pandanaran Semarang will progressively decrease. This happens due to consumers who still doubted the halal products from KFC, KFC issues that support and fund Palestinian attacks against Israel, the motivations from within the consumer to develop the efforts of Muslim entrepreneurs so consumers who have high religiosity chose to eat similar meals in a place owned by Muslim entrepreneurs. Country of origin affects the purchase intention against KFC Pandanaran Semarang products, it is indicated that when consumers have a view that the United States is the country of origin of the KFC has a good product innovation In contrast with other countries, has sophisticated technology, offers a wide selection of quality products, giving it pride in could have a product of the United States is a very advanced country, will encourage purchase intention of consumers against products in KFC Pandanaran Semarang.

Consumer attitudes affect consumer purchase intention on KFC products Pandanaran Semarang, this indicates that when consumers already feel suited and satisfied buying products in KFC Pandanaran Semarang, consumers liked the KFC product because according to with consumer tastes, consumers buying products of KFC because KFC is famous for its excellent taste Ayam may encourage purchase intention against KFC products at Pandanaran Semarang. Consumer attitudes not as intervening variables on the relationship between religiosity towards purchase intention in KFC Pandanaran Semarang. This is due to the large number of consumers who still have any doubt against halal KFC products, besides the existence of the issue in the public that KFC provides funds to Israel to fight the Palestinians, making consumers who have a level religiosity is a good choose directly lower the purchase intention against KFC products at Pandanaran Semarang. Consumer attitudes not as intervening variables on the relationship between country of origin against the purchase intention in KFC Pandanaran Semarang. This is because the countries United States is a very advanced country, making consumers have direct purchase intention against KFC products at Pandanaran Semarang, this is because consumers already feel confident with the product made from a United States State is a very advanced country. In making a product, the United State would've set a high standard of quality. 


\section{REFERENCES}

Abdolvand, M. A., \& Azima, S. (2015). The Role Of Ethnocentrism, Religiosity, Animosity, And Country-Of-Origin Image, In Foreign Product Purchase intention Case Study: Buying Saudi Products By Iranian Consumers. International Journal Of Marketing \& financial Management, 3(11), 71-93.

Ahmed, Z. U., Johnson, J. P., Ling, C. P., Fang, T. W., \& Hui, A. K. (2002). Country-Of-Origin and Brand effects on consumers evaluations of cruise lines. Internasional Marketing Review, 19(3), 279-302.

Ahmed, Z., Anang, R., Othman, N., \& Sambasivan, M. (2013). To purchase or not to purchase US products: role of religiosity, animosity, and ethno-centrism among Malaysian consumers. Journal Of Services Marketing, 27(7), 551-563.

Ancok, D., \& Suroso, F. N. (2008). Psikologi Islami Solusi Islam Atas problem-Problem Psikologi. Yogyakarta: Pustaka Belajar.

. (2011). Psikologi Islami Solusi Islam Atas problem-Problem Psikologi.

Yogyakarta: Pustaka Belajar.

Binalay, A. G., Mandey, S. L., \& Mintardjo, C. M. (2016). Pengaruh Sikap, Norma Subjektif dan Motivasi Terhadap Minat Beli Secara Online Pada Mahasiswa Fakultas Ekonomi Dan Bisnis Di Manado. Jurnal EMBA, 4(1), 395-406.

Dinata, J. S., Kumadji, S., \& Hidayat, K. (2015). Country of origin Dan Pengaruhnya Terhadap Persepsi Kualitas dan minat beli. Jurnal Administrasi Bisnis, 25(1).

Erna, Listiana. (2012). Pengaruh Country of origin Terhadap Perceived Quality Dengan Moderasi Etnosentris Konsumen. Jurnal Administrasi Bisnis Vol 8 No 1, 8(1), 21-47.

Ferdinand, A. (2002). Structural Equation Modelling dalam Penelitian Manajemen. Semarang: Badan Penerbit Universitas Diponegoro.

. (2011). Metode Penelitian Manajemen. Semarang: Badan Penerbit Universitas Diponegoro.

Fuad, Nashori. 2002. Mengembangkan Kreativitas dalam Perspektif Psikologi Islam. Yogyakarta: Menara Kudus.

Ghufron, M. N., \& Risnawita, R. (2010). Teori-Teori Psikologi. Yogyakarta: AR-Ruzz Media.

Haque, A., Anwar, N., Yasmin, F., Sarwar, A., Ibrahim, Z., \& Momen, A. (2015). Purchase intention Of Foreign Product: A Sudy On Bangladeshi Consumer Perspective. Sage Journal, 1-12.

Husein, Umar. (2003). Metode Riset Perilaku Konsumen Jasa (1 ed.). Jakarta: Ghalia Indonesia.

Imam, Ghozali. (2002). Pengaruh Religiositas terhadap komitmen Organisasi, Keterlibatan Kerja, Kepuasaan Kerja, dan Produktivitas. Jurnal Bisnis Strategi, 2. 

. (2009). Aplikasi Analisis Multivariate. Semarang: Badan Penerbit

Universitas Diponegoro.

Jalaluddin. (2001). Psikologi Agama. Jakarta: PT Raja Grafindo Persada. . (2010). Psikologi Agama. Jakarta: Rajawali Pers.

Johnson, B. R., Jang, S. J., Larson, D. B., \& Li, S. D. (2001). Does Adolescent Religious Commitment Matter? A Reexamination of the effects of Religiosity on Delinquency. Journal of Research In Crime and Delinquency, 38(1), 22-43.

Kotler, P., \& Keller, K. L. (2007). Manajemen Pemasaran (12 ed.). Jakarta: Erlangga. . (2009). Manajemen Pemasaran (13 ed.). Jakarta: Erlangga.

Priaji, V. W. (2011). Faktor-Faktor Yang Mempengaruhi Intensi Menabung Di Bank Syariah. Skripsi. Jakarta: Universitas Islam Negeri Syarif Hidayatullah Jakarta

Ramadania, Sri, Gunawan., \& Jamaliah. (2013). Country of origin Effect and Animosity on The Attitude and Purchase intention of Foreign Products. ASEAN Marketing Jurnal, $V(1), 59-68$.

Rehman, A., \& Shabbir, M. S. (2010). The Relationship between religiosity and new product adaption. Journal of Islamic Marketing, 1, 63-69.

Robbins, S. P. (2006). Perilaku Organisasi. (B. Molan, Trans.) Klaten: PT Intan Sejati.

Rohmatun, K. I., \& Dewi, C. K. (2017). Pengaruh Pengetahuan Dan Religiusitas Terhadap Niat Beli Pada Kosmetik Halal Melalui Sikap. Jurnal Ecodemica, 1(1), 27-35.

Sandra, Oliver. (2007). strategi Public Relations. Jakarta: Erlangga.

Schiffman, L. G., \& Kanuk, L. L. (2006). Perilaku Konsumen (7 ed.). Jakarta: Indeks.

Solomon, M. R. (2009). Consumer Behaviour: A European Perspective. New Jersey: Financial Times.

Sugiyono. (2010). Metode penelitian pendidikan: Pendekatan Kuantitatif, Kualitatif, dan $R \& D$. Bandung: Alfabeta. . (2012). Metode Penelitian Bisnis: Pendekatan Kuantitatif, Kualitatif, dan $R \& D$. Bandung: Alfabeta.

Thouless, R. H. (1995). Pengantar Psikologi Agama. Jakarta: Rajawali Pers.

Yasin, N. M., Noor, M. N., \& Mohamad, O. (2007). Does Image Of Country-Of-Origin Matter To Brand Equity? Journal Of Product \& Brand Management, 16, 38-48.

Yasir, Zahri., \& Hafasnuddin. (2017). Pengaruh Religiosity Terhadap Purchase intention Produk/Jasa Bank Syariah Dengan Sikap Konsumen Sebagai Variabel Mediasi (Studi Pada Nasabah Bank Konvensional di Kota Banda Aceh). Jurnal Ilmiah Mahasiswa Manajemen, 2(1), 118-134. 